\title{
Temple symbolism and mission in the pauline churches
}

\section{Leendert Brouwer ${ }^{1}$}

\begin{abstract}
This study explores the role of temple symbolism in the mission of the Pauline churches. It is theoretically informed by Beale's (2004) and most recently Wright's (2013) claim that Genesis 1:28 and 2 should serve as "the controlling paradigm" for mission. Taking the Garden of Eden as an archetypal temple, a 'cosmic mount' that provides a microcosmic portrayal of the cosmos, Beale and Wright don't discuss important concerns about the 'cosmic mount' theory. This study addresses these concerns, providing an alternative interpretation that emphasizes the contextual nature of temple symbolism.
\end{abstract}

Keywords: temple; symbolism; cosmic mount; the sacred; ritual; mission; church; Paul; Eliade; N.T. Wright.

\section{Introduction}

The 'cosmic mount/temple' hypothesis has had widespread influence in Old Testament scholarship and was recently introduced within New Testament studies. Biblical scholars like Clements (1965), Cross (1973), Clifford (1972), Terrien (1978), Fishbane (1998), Levenson (1984), Collins (1998), depending on the phenomenology of religion of Mircea Eliade (1959), have identified various "cosmic mountains" such as mount Zion in Jeruzalem, Gilgal, Mount Zaphon, Sinai, Pergamon, and others.

Besides "cosmic mountains" scholars have likewise identified "cosmic trees" (Widengren 1951, James 1966, Butterworth 1970, Margulis 1971). Eliade $(1960,4: 251)$ suggests that elements of the cosmic tree have been adopted and further developed in the myth of the "tree of life." The trees in Gen 3, Ez 31 and Dan 4 have a cosmic structure, according to Eliade (:251), as they carry the universe and nurture all creatures. Zimmerli, Cross and Baltzer (1979: 146) agree, suggesting that the tree of Ez 31: 3ff is a world tree, with similar features as the trees of Dan 4 (Collins \& Collins 1993:223) and Mark 4: 32.

1 Leendert Brouwer (ThD) is professor of theology at Universidad Peruana Unión. His email address is leendertbrouwer@upeu.edu.pe. This text depends largely on his thesis (Brouwer 2015: 86ff, 93ff, 123ff, 192ff, 207ff, 228-239). Thanks to J.N.J. Kritzinger, B. Oestreich and P. Versteeg for their comments on an earlier draft of this paper. 
Collins \& Attridge (2007:215) suggest that the mountain in Mark 3:13 takes on "connotations of the mountain of God or the cosmic mountain, the place where heaven and earth meet and where a holy man encounters God and the people receive revelation." Likewise, the mountain in Mark 9:2 would "call to mind the mythic notion of the cosmic mountain" in Mark's cultural context (:421). Beale (2004), assuming that the Garden of Eden served as a primordial temple, claims there is a progressive revelation of the temple in the Old and New Testaments (Beale 2004:385). N. T. Wright (2013:385), following Beale (2004), sees here the key to Pauline mission, maintaining that the church "the ekklessia: its unity, holiness and witness" served as the main symbol of "Paul's newly envisaged and constructed world." Both Wright (2013:102) and Beale (2004:400) envision mission as extending the boundaries of the "cosmic temple" until it includes the whole earth.

This study evaluates the "cosmic temple" hypothesis pioneered by Eliade, which serves as the basis of these interpretations and finds it to be based on questionable assumptions. In addition, I make some remarks concerning the methodology used and propose that temple symbolism should be interpreted as a "ritual-like practice." Whereas anthropologists like Turner, Geertz and others see ritual as a substance, Bell (1997:138ff) suggests that daily habits (i.c. the practice of writing apostolic letters) should be seen as substance and ritual as an attribute, hence the term "ritual-like practice." Bell (1992:80) suggests this form of practice has the following features: (1) situational; (2) strategic; (3) embedded in a misrecognition of what it is in fact doing; and (4) able to reproduce or reconfigure a vision of the order of power in the world." These aspects will be discussed below.

\section{The temple as microcosm}

The theory of the temple as a 'cosmic mount,' which goes back to the work of Mircea Eliade, a key representative of the Phenomenology of Religion School, has been used within Old Testament studies and recently also within New Testament studies.

\subsection{The cosmic mountain in Old Testament scholarship}

Clements (1965:2) notes that mountains served as symbols of divine presence in the ancient world. Besides mountains also trees have been suggested as symbol of divine presence. Margulis (1971:482) for example suggests a reading of an Ugaritic text: "A tree (with) its 'head' in the firma[ment]" (see also Margulis 1974). Eliade (1959:33, 38) discusses both in more detail in his writings. He assumes two distinct realms: the sacred and the profane, with an "axis mundi," in the form of a mountain or a tree, connecting both (:36). The whole inhabited world is centered around this axis (:37). In other words, the axis is positioned "in the middle" or at the "navel of the earth" (:37). Eliade's notion of a center, an "axis mundi," is derived from the Pan-Babylonian School. 
the crucial elements in Eliade's symbolism of the "Center" - the cosmological world-mountain where heaven, earth, and underworld are linked, and the replication of this pattern in human acts of construction, in temples and palaces-he largely borrowed from the so-called Pan-Babylonian School (Smith 1987:15; see also Clifford (1972) and Korom (1992:115) for more detail about this school).

The theory consists of three elements (Eliade:39):

1. holy sites and sanctuaries are believed to be situated at the center of the world; 2. temples are replicas of the cosmic mountain and therefore become a center

3. and hence temples constitute the pre-eminent "link" between earth and heaven; The idea of a cosmic mount had a significant influence upon theologians, who argued that the Jerusalem Temple was considered an "axis mundi," providing a link between the sacred and the profane (Fishbane 1998:150, note 6; Levenson 1984:282 and 1985:115, note 44). Biblical scholars like Clements (1965), Clifford (1972), Cross (1973), Fishbane (1998), Levenson (1984), Hayward (1996), Beale (2004), and Walton (2006) have all advanced the hypothesis of a cosmic mount/temple. Levenson (1988:90f) suggests that the Jerusalem temple was a microcosmic portrayal of the cosmos, while its rituals "were thought to allow human participation in the divine ordering of the world."

Not only mount Zion in Jerusalem, but also other "cosmic mountains" have been identified within the ancient world: Gilgal, Mount Zaphon, Sinai, and others. Cross (1973:142) suggested that the sanctuary at Gilgal served as a "cosmic mountain." In addition, Mount Zaphon (mentioned in Isaiah 14:12-15) was considered the dwelling place of Baal in Canaanite mythology. Clements, following May (1962), suggests that there is an allusion to Zaphon in the poem in Ezekiel 28:12-16 (Clements 1965:7, note 2; see also Widengren 1951). This poem is a lament for the king of Tyre and is probably based on an old Canaanite myth. What is important is that the poem identifies "the mount of god" with Eden, "the garden of god."

You were in Eden, the garden of God; ...

With an anointed guardian cherub I placed you ;

you were on the holy mountain of God;

You were filled with violence, and you sinned;

So I expelled you from the mount of god,

And the guardian cherub drove you out

Unlike Ezekiel 28, Genesis 2 does not explicitly say that Eden is on a mountain. Yet, Fishbane (1998:112) observes that the text does suggest that Eden is elevated, because of the "downward coursing streams." Fishbane traces sacred center symbol- 
ism in the Bible from Eden, through the Tower of Babel, the patriarchal period, and the Exodus, to the monarchy. He interprets the Tower of Babel as the "paradigmatic antitype of Eden" and Abraham as a new Adam:

the threefold promise of land, fertility, and blessing given to Abraham effectively reverses the curses of the expulsion and so establish him as a new Adam. This point is structurally enforced by the fact that Abraham is born ten generations after Noah, who was himself born ten generations after Adam and proclaimed as the one who would "comfort us from our work and painful toil on the earth which YHWH has cursed" (Genesis 5:29; cf. 3:17; Fishbane 1998:112).

The transition from Sinai to Zion as cosmic mountain was promoted by Davidic court theologians who began to exalt Jerusalem as the new Sinai (Fishbane 1998:114). This transfer was irreversible, "YHWH came to be designated no longer as "the One of Sinai," but as "he who dwells on Mount Zion" (Levenson 1985:91). Levenson points out that

the transfer of the divine home from Sinai to Zion meant that God was no longer seen as dwelling in an extraterritorial no man's land, but within the borders of the Israelite community. This, in turn, means that the anarchistic tendencies associated with the Sinaitic traditions ...... will be somewhat mitigated or altered in the Zion traditions, which will see YHWH as less remote from the ordinary governance of human society" (Levenson 1985:91).

Levenson also suggests that "a pledge of divine support for a human dynasty" emerging within the Zion tradition, was unthinkable within the Sinai traditions (1985:92).

From a group of characteristics of those cosmic mountains, developed by Eliade, Levenson (1984:282) selects two features: the Temple Mount is central and primordial / protological. The latter does not mean that the mount is uncreated, but merely that it was prior to creation and perfectly preserved (Levenson 1984:282, 283).

The evidence for the cosmic temple hypothesis is mainly found within sources of Second Temple Judaism, but some scholars also identify the bible as source. Yet, even within the writings of Second Temple Judaism the association of temple and cosmos is not always made directly. Hayward (1996) comments that Liber Antiquitatum Biblicarum

directly associates the Temple Service with the continuing stability of the contemporary order of the world. Other texts [LB: Ben Sira, Jubilees, etc] . . . . are aware of this association, but express their perceptions using different language (Hayward:6). 
Beale concurs that the Garden of Eden depicted as the first archetypal temple has first been noticed within Second Temple books such as Jubilees, Testament of Levi, 1 Enoch and also within the Qumran community.

Besides Hellenistic Judaism, Levenson (1984:284, 285) also finds evidence within the bible. He notes that William Foxwell Albright had already suggested in 1950's that various "aspects of the Temple of Solomon must be understood as cosmic symbols." Levenson provides various examples of cosmic symbolism in the description of the altar, the menorah, etc and concludes "in spite of the inevitable uncertainty in individual instances, the cumulative weight of the cases of alleged cosmic symbolism, combined with the literary correspondences . . . . . argues potently in favor of the hypothesis that the Temple in Jerusalem was indeed conceived as a microcosm" (1988:95). Beale (2004:25) agrees and amplifies this thesis saying "that the Old Testament tabernacle and temples were symbolically designed to point to the cosmic eschatological reality that God's tabernacling presence, formerly limited to the holy of holies, was to be extended throughout the whole earth."

\subsection{Extending its boundaries}

Beale mentions two interpretive keys: the first key is "the image of God's glorious presence in a garden-like temple." He suggests this presence forms "an inclusion or kind of 'book-end' structure around the entire canon" (Gen 2 and Rev 21:1 - 22:3) and helps understand "the material about the temple throughout Scripture." The other interpretive key is the temple's cosmic symbolism, "which pointed to the goal of its own extension to become co-equal with the cosmos itself" (Beale 2004:385). Assuming Genesis 1:28 and 2 as "controlling paradigm," Beale comments

later temples and prophecies of the end-time temple usually allude to one or both of these Genesis passages, so that these early Genesis texts provide the interpretative controls for understanding the progressive revelation of the temple in the old and New Testaments (Beale 2004:385).

Beale (2004) connects temple and mission through "the controlling paradigm" of Genesis 1:28 and 2, where Adam is given the task to fill and subdue the earth. He depends on Walton (2001), who interprets this commission of Adam as follows

if people were going to fill the earth [according to Genesis 1], we must conclude that they were not intended to stay in the garden in a static situation. Yet moving out of the garden would appear a hardship since the land outside the garden was not as hospitable as that inside the garden (otherwise the garden would not be distinguishable). Perhaps, then, we should surmise that people were gradually 
supposed to extend the garden as they went about subduing and ruling. Extending the garden would extend the food supply as well as extend sacred space (since that is what the garden represented) (Walton 2001:186; cited in Beale:85).

Beale (2004:400), following Walton, who takes the two creation accounts (Gen 1 and Gen $2 \& 3$ ) together, claims that "extending the boundaries of the temple" is "what 'missions' is all about."

The commission that Adam received was passed on to the Patriarchs. The tabernacle and temple in ancient Israel were meant to re-establish the garden sanctuary of Eden (Beale 2004:66ff). Beale goes on from there showing the end-time purpose of the temple and from there the role of the temple in the New Testament and the mission of the church (2004:123ff). He asserts that Jesus Christ was the temple of the new creation (2004:192ff). And in Paul the church is a temple and that this temple is meant to extend its boundaries until Christ's return when it will have covered the earth.

N.T. Wright (2013:102) recently endorsed Beale's (1994) line of interpretation. As Meeks (1983:6) did earlier, also Wright (2013:29, 351ff), following Geertz, seeks to provide a "thick description" of Paul, using various elements of Paul's "worldview," such as symbols, stories, praxis, and questions. He assumes that Paul shared a narrative framework with Second Temple Judaism, and he (2013:21 note 59) argues that Paul engaged in a revision of various symbols within the Jewish worldview in service of the worldwide mission.

Claiming (2013:358) that the Temple was the central symbol of ancient Judaism, he suggests that Paul made a "central worldview-revision" when he replaced the Jerusalem temple with Jesus, and, "secondarily and derivatively, with his people." Wright suggests that Paul further developed this symbol:

the Messiah's people, and the tasks they perform 'in the Messiah', are described in terms which reflect the people at the centre of Jerusalem and the Temple and the tasks they performed there. They were priests, offering sacrifices, indeed offering themselves as sacrifices, or, in Paul's case, bringing the gentiles themselves as a quasi-sacrificial offering, with a kind of heavy irony, to Jerusalem. And Jerusalem itself, the focus of the longed-for centripetal pilgrimage of the nations, has been replaced by Jerusalem as the centrifugal originating point of the world mission. The redeemer does not now come to Zion but from Zion, going out into all the world to 'gather the nations', not by their coming to the central symbol of ancient Judaism, but by their becoming the central symbol (Wright 2013:358).

Wright suggests Paul is "redrawing the symbolic map of Judaism," besides the temple also other symbols were transformed, in particular the Torah, Land and family 
(2013:367). The latter, also "the community of baptized believers, rooted by that baptism and by that faith in the Messiah himself, became for Paul not only the central locus but also the key visible symbol of the transformed worldview" (2013:369). In other words, "the ekklēsia: its unity, holiness and witness," Wright (:385) claims, serves as the main symbol of "Paul's newly envisaged and constructed world."

This study asks whether the cosmic temple hypothesis is useful for mission studies and Pauline studies, as Beale 2004, C.J.H. Wright 2006:334 and N.T. Wright 2013:101-103 claim.

\section{Evaluation of cosmic mount hypothesis}

Temple symbolism is based on various questionable assumptions, namely the very idea of a cosmic mountain, the distinction between sacred and profane, the idea of a center of the Old Testament, and the idea of mission as "extending boundaries." Besides these assumptions, also the method used is problematic.

\subsection{Cosmic mountain}

In his study of two sacred centers in Jerusalem (the Temple and the Church of the Holy Sepulcher) J.Z. Smith (1987:2) evaluates Eliade's interpretation of the Tjilpa myth of the sacred pole. This pole made land habitable "by maintaining contact with the sky . . . . , the "transhuman" realm of the sacred, of transcendence. The pole is similar in function to ancient Indian and Near Eastern temples, with the only difference that it is portable $(1987: 2)$.

Smith criticizes Eliade's account of the sacred pole, which allegedly represented a sacred center that connects heaven and earth. Smith notes that Eliade used only one source and by re-reading this source, namely Spencer and Gillen's account of the Tjilpa and their pole, he $(1987: 4,10)$ finds that Eliade's interpretation is not warranted. Citing Roheim, Smith (:11) suggests that these myths are about anthropology not cosmology: "Looking at the kernel of these frequently tedious [ancestral] narratives we are struck by one feature: in all of them environment is made out of man's activity. ... This is a man-made world. Environment is regarded as if it were derived from human beings." Smith also claims there is no evidence for a central cosmic mountain that served as an "axis mundi" in ancient Near Eastern sources (:17). Consequently, Eliade's thesis of the temple as the "Center" of the cosmos turns out to be false.

Smith refers to R.J. Clifford's dissertation, The cosmic mountain in Canaan and the Old Testament, which was written under the supervision of Frank Moore Cross, who himself claims, as seen above, the existence of a cosmic mountain at Gilgal. While Clifford (:9ff) notes that modern students of Mesopotamian culture avoid using the concept "Weltberg," advanced by Assyriologists, to describe Mesopotamian speculation about the cosmic center. He nevertheless maintains that the Mesopotamian sources do provide 
evidence for "a cosmic center, where heaven and earth are united." And this cosmic center "appears in some texts to be commemorated by a shrine or temple."

Likewise, Clifford (:180) acknowledges difficulties with calling mount Zion and mount Sinai "cosmic mountains," but he still claims that even though "the Solomonic Temple cannot be proved in its individual elements to have reflected the cosmos or structure of the universe," nevertheless "it undoubtedly reflected the heavenly temple." In the below paragraph on "method," the role of evidence for a cosmic center is further discussed. Besides the very idea of a cosmic center, there is also discussion about Eliade's concept of the sacred.

\subsection{Sacred and profane}

Eliade considers 'sacred' not an attribute but a substance. The use of the substantive "The Sacred" goes back to Durkheim and is used widely within religious studies (Smith 1987:105). Eliade assumes two distinct and opposed realms of the sacred and profane, which need to be connected through an "axis mundi." Yet, the distinction between sacred-profane is contested. The anthropologist Goody says this distinction is inherent in the perspective of the observer. Any attempt to situate it in the perception of the actor and declare it universal, as Durkheim did, must be rejected. Goody's own fieldwork among the LoDagaa people in northern Ghana and the work from the anthropologist Evans-Prichard among the Zande people of Sudan both show that these people did not know about it (Goody 1961:151).

Besides the assumption of two distinct and opposing realms (the sacred and profane), there is discussion about the assumption that sacred is a substantive rather than an attribute. J.Z. Smith (1987:105) claims that, "ritual is not an expression of or a response to "the Sacred"; rather, something or someone is made sacred by ritual." He (1987:105) comments that a carpenter makes from the same piece of wood both a sacred object and a household utensil. The difference is in the act of consecration. Smith observes (:106) that Durkheim had also noted this use of the sacred.

In summary, the use of the substantive "the sacred" has only emerged with Durkheim. It is thus anachronistic to project this category on the ancient world, in particular ancient Israel. Also, the distinction between sacred-profane is not universal. Yet, even if all this were possible, it would still be necessary to raise the question whether the idea of a sacred center (i.c. a cosmic mountain) can serve to unify the Bible. This question is a matter of debate among Old Testament scholars.

\subsection{Center of the Old Testament}

Hasel (1972:119-133) distinguishes various "centers" of the Old Testament that have been suggested: "Covenant" (Eichrodt), "The holiness of God" (Sellin), "God as the Lord" (Köhler), "Israel's election as people of God" (Wildberger), "The 
rulership of God" (Seebass) or Kingdom of God (Klein), "promise" (Kaiser), "the rule of God and the communion between God and man" (Fohrer), "communion with God" (Vriezen), "The presence of God" (Terrien), "Yahweh the God of Israel, Israel the people of Yahweh" (Smend), "Deuteronomistic theology of history" (von Rad), "exclusiveness and uniqueness of Yahweh as expressed in the first commandment"(Schmidt, Zimmerli). The "cosmic temple" could be added to this list.

Hasel (:137) objects to a method that superimposes a "center upon the diverse and manifold encounters between God and man over so long a period." He neither sees nor anticipates that a consensus will be reached on any of these centers (:139). He suggests instead a minimal definition of a center of the Old Testament, namely God as the dynamic, unifying center of the Old Testament (:140). This means that not only the idea of a cosmic mountain needs to be rejected, but also the idea that it helps to unify the Bible.

Being sensitive about the relation between empire and culture/religion (Said 1994), this study also raises a concern about the very idea of mission as an activity of extending boundaries (of the cosmic temple).

\subsection{Extending the boundaries}

Beale's interpretation of mission as extending the boundaries can easily be confused with the conquest of territory. The metaphor of 'extending boundaries' is highly suspect in light of the history of mission and colonialism, as described by Neill (1966). Bosch (1991:303) notes that modern missions began in the era of modern Western colonialism. From the 15th until the 17th century the assumption of the colonizing powers was "that the conquered nations would also have to submit to the Western ruler's religion" (:303). From the 17th century onwards colonialism was secular and only in the 19th century, colonial authorities invited missionaries to their territories "to persuade unwilling "natives" to submit to the pax Britannica or the pax Teutonica." Bosch (1991:304) remarks "it should therefore come as no surprise that, during the entire "high imperial era" (18801920), examples abounded of government spokespersons praising the work of missions or missionaries."

Those missions were primarily accountable to the colonial administration. However, accountability should be directed towards God and is linked with the expectation of the 'final judgment.' While Wright (2013:483) affirms that the 'final judgment' remains "within the rethought worldview of Paul the apostle," which he adopted from Second Temple Judaism, the concept of 'mission as extending boundaries' disregards the possibility that these missions themselves, the missiones ecclesiae, fall under this judgment. 
There is a consensus among missiologists about taking Missio Dei as the point of departure for a study of the missiones ecclesiae (Bevans, Bosch, Hartenstein, Hoekendijk, Kirk, Newbigin, Rahner, Schreiter, Shenk, Sundermeier, Verkuyl, Vicedom). This approach could help to prevent a confusion of mission and colonialism. Yet, Wright (2013) does not mention Missio Dei in the index.

Different from Wright's suggestion that the ekklēsia serves as the main symbol in Paul's worldview, Beker (1980:317) cautions that Paul "in all probability does not use ekklēsia as a polemical term." This means that "neither the salvation-historical fulfillment and displacement of Israel, nor its catholic universality, is central in Paul's use of the term. Instead, he emphasizes the local congregation in its concrete gathering for worship and in its present, contingent activity." The next paragraph contrasts Beale's and Wright's method with the one used within this study, which emphasizes the contingent nature of temple symbolism within Pauline letters.

\subsection{Method}

Phenomenology of religion, associated with the names of Mircea Eliade, Gerardus van der Leeuw and others, focused on religious experience. Waardenburg (1978) draws further distinctions within this school. The division between the phenomenological and historical dimension of religious phenomena that is made within this approach, seems to resemble the platonic distinction between content and form. Phenomenologists typically start in a platonic fashion with universal patterns of thought (e.g 'the center' - Eliade) which determine particular/historical forms of religion.

Significantly, Eliade (1959:34) called Plato "the outstanding philosopher of "primitive mentality." Eliade suggests that "primitive mentality" tends to be archetypal.

an object or an act becomes real only insofar as it imitates or repeats an archetype. Thus, reality is acquired solely through repetition or participation; everything which lacks an exemplary model is 'meaningless,' i.e. it lacks reality. Men would thus have a tendency to become archetypal and paradigmatic (Eliade 1959:34).

This means that the "sacred center" in "primitive societies" is not an empirical concept but a platonic idea. Clifford (1972:7) hints at this issue, without being explicit, when he comments that whereas phenomenologists "assume the psychic unity of mankind," this assumption "raises serious philosophical and psychological questions."

Assuming a universal pattern of thought, in line with Eliade, Fishbane (1998) has argued that the idea of the cosmic temple has had a continued influence within the religion of Israel. Levenson (1988) applies this insight to the Jeru- 
salem temple. Following Eliade, he (1984:282) centers on two important notions, namely "that the Temple Mount is central and that it is primordial." These notions have been adopted by Beale (2004) and Wright (2013), who maintain that the "Garden of Eden" served as an archetypal temple and that this idea of a cosmic center is central in the development of the Old and New Testament. Beale (2004:25), as mentioned above, argues "that the Old Testament tabernacle and temples were symbolically designed to point to the cosmic eschatological reality that God's tabernacling presence, formerly limited to the holy of holies, was to be extended throughout the whole earth." Wright (2013:2, note 59) adopts this position, claiming, as noted above, that "the ekklēsia: its unity, holiness and witness" served as the main symbol of "Paul's newly envisaged and constructed world."

Smith (1989: 17) rejects the idea of a "Center" as "a universal (or even dominant) pattern of symbolization." He does not say it is mere fantasy. Rather, Smith (:17) maintains "the burden of proof has shifted to those who will claim that a particular cultural construction represents a "Center." The "Center" is not a secure pattern to which data may be brought as illustrative; it is a dubious notion that will have to be established anew on the basis of detailed comparative endeavors."

Rather than starting with (platonic) concepts/symbols as a substance, this study assumes symbolism to be an attribute. This means that this symbolism is studied as an aspect of daily practice, i.c. the writing of apostolic letters. Thus, temple symbolism in the Pauline letters is interpreted as a "ritual-like practice". The local congregation (i.c. the church at Corinth) is thus put in the center, "in its concrete gathering for worship and in its present, contingent activity" (Beker 1980:317).

\section{Ecclesial symbolism in Corinth}

Temple symbolism is found in various letters from Paul. In Romans, for example, Paul appeals to the church members that they present their "bodies as a living sacrifice, holy and acceptable to God" (Rom 12:1) and portrays himself as a priest, "a minister of Christ Jesus to the Gentiles in the priestly service of the gospel of God, so that the offering of the Gentiles may be acceptable, sanctified by the Holy Spirit (Rom 15:16). In his letter to the Philippians Paul talks about his work as "being poured out as a libation over the sacrifice and the offering ( $\pi \rho \circ \sigma \phi \circ \rho \alpha$ ) of your faith" (Phil 2:17). In Phil 2:14, Paul admonishes the church members "Do all things without murmuring and arguing, so that you may be blameless and innocent,

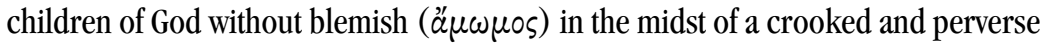
generation." Lev 9:2, 3 (LXX) mentions "without blemish" is an attribute of a sacrificial animal (see also Lev 22:19 and Ez 43:25). 
In the following paragraphs the focus will be on the church in Corinth, which experienced various problems: divisions, sexual immorality, gifts of the Spirit, etc. Paul addresses them through symbolism, in particular the symbolism of a building, temple, body, Passover and a cosmic battle.

\subsection{God's building}

In Corinth the church members were quarreling and Paul warns against division $(\sigma \chi i \sigma \mu \alpha)$. Some said "I belong to Paul" and others "I belong to Apollos" or "I belong to Cephas," or "I belong to Christ" (1 Cor 1:12). This quarrel about status could potentially divide the church. In 1 Cor 3 Paul returns to the issue of quarreling among the Corinthians, introducing the "field" and "building" metaphor, which structure the experience of this conflict. The metaphor of the church as a field goes back to the image of Israel as God's vineyard, a familiar image in the Old Testament (Isaiah 5:1-7; Psalms 80:8). Paul first defines the role of Apolllos and himself as servants, who have been assigned by the Lord.

What then is Apollos? What is Paul? Servants ( to believe, as the Lord assigned to each. I planted, Apollos watered, but God gave the growth. So neither the one who plants nor the one who waters is anything, but only God who gives the growth (1 Cor 3:5-7).

Servant-Lord terminology, belonging to the sphere of the household, establishes hierarchy within the situation. As a result, the focus shifts from the role of Paul and Apollos (Paul planting and Apollos watering), to "God who gives the growth." Consequently, the claims "I belong to Paul," or "I belong to Apollos," both of which serve as appeals to a privileged status within the community, lose their power.

Paul then shifts his attention from the proclaimed authorities (Paul, Apollos, Cephas) to the role of the church members: he says "you are God's field, God's

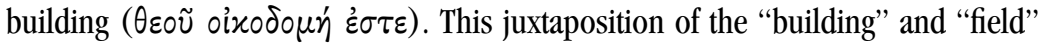
metaphors, has ramifications for Paul's position within the church. His role is no longer simply a servant, but is now defined as a "competent master-builder"

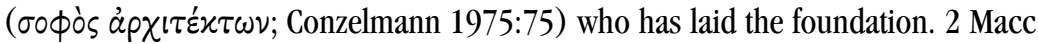

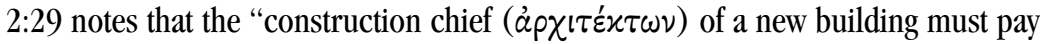
attention to the entire structure" (translation Doran 2012:65). As a skilled master builder, Paul then tells the church members that the foundation that has been laid is Jesus Christ and issues an implicit warning to those who built upon this foundation.

Now if anyone builds on the foundation with gold, silver, precious stones, wood, hay, straw — the work of each builder will become visible, for the Day will disclose 
it, because it will be revealed with fire, and the fire will test what sort of work each has done.

If what has been built on the foundation survives, the builder will receive a reward. If the work is burned up, the builder will suffer loss; the builder will be saved, but only as through fire (1 Cor 3:12-15).

The order of the building materials, respectively gold, silver, precious stones, wood, hay and straw, shows that the sequence is determined by the fire test. Hay and straw disappear instantly, while wood takes time. Precious stones may get damaged, and silver and gold not only survive but become purified through fire. The church members may have had another association as well, namely the link between silver and gold and the word of God. The Psalms, which were commonly recited in synagogues in those days (Moore 1970), depict these metals as a symbol for the Torah (Ps 12:6; 119:72, 127). In other words, those who build on the foundation, which Paul has laid, they better use the right materials (the Torah/word of the Lord) when they do their work.

Besides being concerned about a proper foundation and building materials, Paul as the master-builder, also commends the practice of "building up"

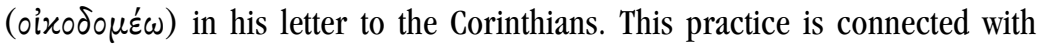
several divisive issues. For example, the church members were divided about eating meat sold in the market, which had been sacrificed to idols. Paul draws the practice of eating this meat within the context of the symbol of the household (oikos). He does not force or oblige the members to refrain from eating this meat, but he commends "all things are lawful, but not all things build up"

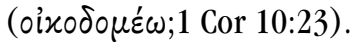

Likewise, with the issue of spiritual gifts, Paul consistently uses the image of

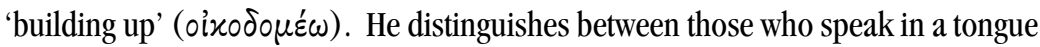

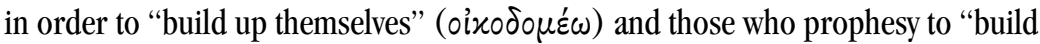

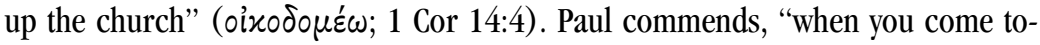
gether, each one has a hymn, a lesson, a revelation, a tongue, or an interpretation.

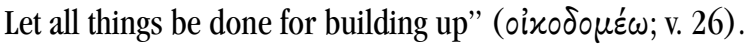

As "gifts of the Spirit" these practices give evidence of God's presence within the community, provided that they contribute to "building up" the church rather than one-self. In other words, God's presence among his people is contingent upon the practice of "building up." As Paul draws these gifts/practices, and in particular the gift of speaking in tongues, within the context of the temple metaphor, he redefines the sacred. God dwells not in the temple in Jerusalem, but in the community, as he says, "you are the temple." He suggests that various practices within the church ought to help "build up" this dwelling place. 
While he commends the activity of "building up" the church, he also warns against the opposite, namely its destruction. He uses temple symbolism to address this issue.

\subsection{God's temple}

The attention for the quality of the building materials (gold, silver, precious stones, wood, hay and straw) makes a transition possible to the rhetorical question: "Do you not know that you are God's temple (vaós) and that God's Spirit dwells in you"

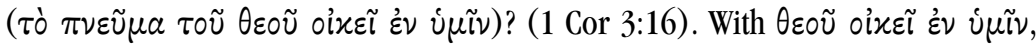
Paul says that God dwells in you (plural). God dwells (oixei from oikos) in the group as a whole: "you are the temple," not "you are temples" (see also in 1 Cor 6:19 where the temple metaphor is used for an individual believer).

He then adds that God's temple is holy (v.17). In other words, sacrality is ascribed to the community as a whole. This emphasis on the community differs from a modern emphasis on the individual, where spiritual gifts, in particular healing, create an image of the sacred self (Csordas 1994). Sacrality can be attributed to a variety of things: objects, places, buildings (temple), groups and persons (Bell, p.157).

Besides the "field" and "building" metaphor, this temple symbolism also structures the experience of the conflict. With temple symbolism the concern for purity is introduced, which served as a principle of hierarchy and separation in the ancient world. Dumont (1998:59) explains "the opposition of pure and impure appears to us the very principle of hierarchy, to such a degree that it merges with the opposition of superior and inferior; moreover, it also governs separation." Consequently, the quarrel about status (I belong to Paul, etc) within the context of temple symbolism enables Paul to move beyond the warring parties and warn "if anyone destroys God's temple, God will destroy that person" (v.17).

Another example of the principle of hierarchy and separation related to the opposition pure-impure, is given in 1 Cor 5 . The text deals with a case of sexual immorality. When Paul hears that one of the church members is "living with his father's wife," he deems this an act of "sexual immorality" ( church members "not to associate with, not even to eat with" him.

He then commands them "drive out the evil person from you." The latter is an implicit reference to Mosaic Law, going back to Lev 18, which stipulates "You shall not uncover the nakedness of your father's wife; it is the nakedness of your father . . . . For whoever commits any of these abominations shall be cut off from their people" (Lev 18:8,29). In his comments on Lev 18, Milgrom (2000:1573) distinguishes between ritual and moral impurity. Whereas the former is remediable, the latter is not: "It is a capital crime, punishable for the individual by kâret and for the 
community by exile." So, when Paul gives the imperative "Drive out the evil person from you," he means exclusion from the meal gatherings. Conzelmann (1975:102) confirms "the demand for the suspension of table fellowship is general. It is not to be restricted to community meals (with Kümmel; see also Anderson 2008:76)."

The exclusion from the Corinthian meal gatherings is also fostered through household symbolism. While the church members in Corinth are steadily depicted as a community of $\dot{\alpha} \delta \varepsilon \lambda \phi \circ$, especially through the use of the vocative of $\dot{\alpha} \delta \varepsilon \lambda \phi o ́ s$ in verse 6, 20, 26 and 39, Paul shows uncertainty about the identity of those who are sexually immoral, greedy, or an idolater, reviler, drunkard, or robber. He refers to

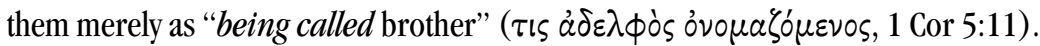
He thus suggests implicitly that the Corinthians could not presume upon their identity as brothers, members of the household.

\subsection{Christ's body}

Besides the building and temple metaphor, Paul also uses the body metaphor to structure the experience of divine worship in Corinth. Church members made various contributions through hymns, prophecies, etc. The body metaphor helps people see the significance of the individual person within the whole. Each person makes a unique and necessary contribution to the whole. This means each person is needed for the whole to develop: "If all were a single member, where would the body be?" Paul asks.

The aspect of being unique is also important within a relationship of love. The other person does not merely have an instrumental but an intrinsic value. Whereas the former merely promotes one's own interests, the latter takes the interests of the other at heart and therefore requires that the other has intrinsic value (Brümmer 2006:296). While with the former, the other could be replaced by anybody else who can serve this same purpose, with the latter the other person is considered unique and irreplaceable.

With the value of each individual established, and thereby rejecting both attitudes of inferiority (12:14-20) and superiority (:21-26), Paul then focuses on the need for inter-dependence. Self-sufficiency is impossible within the body metaphor, since each member is in need of the other to survive and grow.

As it is, there are many members, yet one body. The eye cannot say to the hand, "I have no need of you," nor again the head to the feet, "I have no need of you" (1 Cor 12:20-21).

Paul then adds an interesting detail to this picture, which fits the natural body, and is subtly directed against the attitudes of inferiority and superiority that were held 
at the common meal described in 1 Cor 11 . This move shows that the body metaphor is governed by the model of love/fellowship. Paul stresses that the weaker, less respectable members of this body are all the more indispensable, and should therefore receive more honor. He thus takes the honor ethic, which was important within the Greek-Roman world (Cairns 1993, Barton 2001), and turns it upside down and puts love on top of the hierarchy of values within the Christian community. Against the claim that Paul merely borrowed from the Stoics rather than from Jesus (Bultmann 1924, Dibelius 1927, Engberg-Pedersen 2000, Lee 2006), this analysis of body symbolism in the Corinthian church shows that Paul acknowledged the "last will be first' ethic, espoused by Jesus (Mt 20:16).

On the contrary, the members of the body that seem to be weaker are indispensable, and those members of the body that we think less honorable we clothe with greater honor, and our less respectable members are treated with greater respect; whereas our more respectable members do not need this (1 Cor 12:22-24).

Note that he first writes here "the members" and then switches to "our members." So, through the image of the human body he now addresses the situation within the church in Corinth explicitly. The church consisted of less respectable and more respectable people. Paul also gives an additional reason why more honor is (should be) given to these less respectable members: prevent dissension by fostering care for one another (1 Cor 12:24-26).

\subsection{Passover}

In the previous paragraphs various forms of symbolism have been mentioned through which Paul sought to address problems within the church in Corinth, such as divisions, sexual immorality, gifts of the Spirit, etc. Besides the building, temple, and body metaphors, this paragraph discusses the use of Passover symbolism. In 1 Cor 5:2, 6 Paul first admonishes the members that instead of taking an attitude of mourning they are arrogant and boast while one of the members "is living with his father's wife" (1 Cor 5:1). Martin (1995:169) suggests "Paul's main concern is with the health of Christ's body; the man's individual fate is secondary," for he does not focus on the destiny of the individual: "Paul does not say that the man's flesh must be destroyed so that $h i s$ spirit will be saved. He simply speaks of the flesh and the spirit" (:169). Fitzmyer (2008:240) concurs "Paul is not so much concerned about the sin of the individual as he is about the smugness of community members in tolerating such a wrongdoer among them, which jeopardizes their status in God's sight and will not be in their interest on the Day of the Lord; hence his recommendation of the exclusion of all that is immoral" (see also Anderson 2008: 74). 


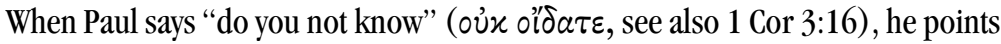
to a familiar issue, the Passover. Conzelmann (1975:98), following Lietzmann, suggests Paul first points to a proverb about leaven and then in verse 7 makes the association with Jewish Passover. This may be the case, but the Passover symbolism, not the proverb, is in focus. Paul portrays Corinthian meal gatherings as Passover festivals in order to address the arrogant attitude of the church in the face of sexual immorality ( $\pi \circ \rho v \varepsilon i \alpha)$. Paul depicts this immoral practice within the church as the yeast that had to be removed during Passover.

Your boasting is not a good thing. Do you not know that a little yeast leavens the whole batch of dough? Clean out the old yeast so that you may be a new batch, as you really are unleavened. For our paschal lamb, Christ, has been sacrificed. Therefore let us celebrate the festival, not with the old yeast, the yeast of malice and evil, but with the unleavened bread of sincerity and truth" (1 Cor 5:6-8).

The Mosaic Law required that no yeast is being used during the Passover. It even prohibits that yeast was kept in the house.

For seven days no leaven shall be found in your houses; for whoever eats what is leavened shall be cut off from the congregation of Israel, whether an alien or a native of the land. You shall eat nothing leavened; in all your settlements you shall eat unleavened bread (Ex 12:19-20).

Through this symbolism, the removal of the yeast (expulsion) is not at the discretion of the church, with its attitude of arrogance, but has become a basic condition for celebrating the festival (meal fellowship).

Paul's use of Passover symbolism is an example of what the anthropologist Grimes (1990:199ff) called "ritual defeat." Grimes says "in a ritual defeat one ritual performance invalidates another." Ritual defeat is often followed by "ritual theft." Grimes suggests the latter is "the plundering of a conquered ritual system for its symbolic wealth." This study interprets Paul's use of the phrase "let us celebrate the festival" as an example of the "ritual theft," as this phrase depends and assumes that the Jewish Passover is replaced with the fellowship meals within the Christian churches.

\subsection{Cosmic battle}

Some members in the Corinthian church were beginning to say that there is no resurrection. This was another point of contention in Corinth, which Paul addresses through the symbolism of a cosmic controversy between Christ and "every ruler 
and every authority and power" (1 Cor. 15:24). Paul suggests that "if Christ has not been raised, then our proclamation has been in vain and your faith has been in vain. We are even found to be misrepresenting God, because we testified of God that he raised Christ—whom he did not raise if it is true that the dead are not raised" (1 Cor. 15:14- 16).

The framework of a cosmic controversy is important for both Paul's proclamation as well as for the life of the church. When Paul says "you are to hand this man over to Satan," he shifts the focus of the controversy in the church. This is an apocalyptic aspect; it is situational and strategic. It shifts the focus from the church to a cosmic controversy, where the power of Christ and the power of Satan take center stage. Through the practice of expulsion the church participates in this controversy. The apocalyptic framework de-centers the church community and thus makes her attitude of arrogance redundant.

This does not mean that the individual, who committed the sexual offence, is not held responsible for his/her choices. Within this apocalyptic framework it was coherent that humankind was portrayed both as being under the rule of the powers outside and at the same time being held responsible for its choices (Brouwer 2015:94- 96).

Paul talks about the exclusion from the church gathering and thus meal fellowship. In verse 2 he talks about "removed from among you" and in verse 4 he

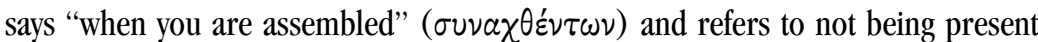

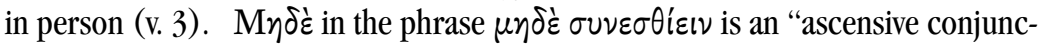
tion," which serves to provide a further focus on the issue of exclusion; exclusion means elimination from the common meal as Paul says "not even to eat with such a person." With the imperative "drive out the wicked person from among you," Paul draws the practical conclusion. When the church members are not to eat with a person, this means essentially that the person has no place in their gatherings.

\subsection{Reconfiguration of the vision of the order of power}

Through these various forms of symbolism, Paul reconfigures the vision of the order of power within the church. The symbol of the kingdom and cosmic controversy de-centers the church community and thus makes her attitude of arrogance futile (1 Cor. 5:1,2). Through the Passover symbolism, the expulsion of the immoral person (removal of the yeast) is not at the discretion of the church, but is identified as a basic condition for the celebration of the Passover festival (i.c the Corinthian meal fellowship). Through household symbolism, the Corinthians could not presume upon their basic identity as brothers ( $\dot{\alpha} \delta \varepsilon \lambda \phi o ́ s)$, members of the household. Through temple symbolism, the opposition of pure-impure is introduced, which implies a principle of hierarchy and separation. Through body symbolism Paul turns the honor ethic upside down: those who are weak and less respectable de- 
serve more honor. Finally, through the building symbolism Paul bolsters his own position as "master builder" from which he can oversee "the entire structure": the foundation, building materials and building practice.

\subsection{Symbolism and mission}

With Bell and against scholars like Staal (1970), Humphrey and Laidlaw (1994) and others, who hold that ritual practice (i.c. the use of symbolism) does not involve human intention and is therefore meaningless, this study assumes that rituallike practice involves strategic action. These practices created and maintained the church as an open network, which accounted for the growth and development of the church (Brouwer 2015:213).

The church as a network society is a pre-modern phenomenon. Taylor $(2007: 158,282,368)$ sees a transition from a "network" towards a "categorical" form of society. The latter society emerged in the 18th century and consists of relations "bound together by codes" (2007:282). Following Ivan Illich, Taylor (:737ff) sees a development towards the categorical within both society and church. Modern democracies [including the church] are governed by the "categorical" form. People also 'belong' in these societies, but to "ever wider and more impersonal entities: the state, the movement, the community of humankind" (2007:211). Alternatively, a network is bound together by personal relations of kinship. This study assumes that ritual-like practices (i.c. the use of (temple) symbolism) played an essential role in the creation and maintenance of these networks.

\section{Ecclesial mission in Corinth}

The sociologist Stark (1996) uses network theory, which is an application of the control theory of deviant behavior, to explain the growth of early Christianity. The control theory of deviant behavior, assumes that conversion "is not about seeking or embracing ideology; it is about bringing one's religious behavior into alignment with that of one's friends and family members" (Stark 1996:17). Social deviance is understood against the background of Durkheim's theory of social integration. Stark and Bainbridge (1996) say

Persons will conform to the norms to the extent that they are attached to others who accept the legitimacy of the norms. Conversely, people will deviate from the norms to the extent they lack attachments (Stark and Bainbridge 1996:5).

At a group level "deviance rates will be higher in groups having a lower mean level of attachments" (:5). They (:7) further claim that "religious individuals will be less likely than those who are not religious to commit deviant acts."

Within Stark's network theory of conversion, the Pauline churches did not grow because of doctrine being preached but because of social networks, "through a 
structure of direct and intimate interpersonal attachments" (:20). Each new member expanded the size of the network of attachments between group and potential converts (1996:21). Meeks concurs

The centrality of the household has a further implication for the way we conceive of the Pauline mission: it shows our modern, individualistic conceptions of evangelism and conversion to be quite inappropriate. If the existing household was the basic cell of the mission, then it follows that motivational bases for becoming part of the ekklesia would likely vary from one member to another. If a household became Christian more or less en bloc, not everyone who went along with the new practices would do so with the same understanding or inner participation. Social solidarity might be more important in persuading some members to be baptized than would understanding or convictions about specific beliefs. Differential qualities and degrees of engagement with the group from the beginning would not be surprising (Meeks 1983:77)

When evaluating Stark's position within the context of the western philosophical tradition, which since Plato has advocated the priority of mind over the body, thought over action, Stark appears to reverse this priority when he claims that conversion "is not about seeking or embracing ideology; it is about bringing one's religious behavior into alignment with that of one's friends and family members" (Stark 1996:17). This implies that growth occurred not through kerygma but koinonia, "through a structure of direct and intimate interpersonal attachments" (Stark:20).

Bell's (1992:221) position agrees in some respect with Stark, as she claims that ritual-like activities are not "a matter of transmitting shared beliefs, instilling a dominant ideology as an internal subjectivity, or even providing participants with the concepts to think with." She further clarifies "Ritual symbols and meanings are too indeterminate and their schemes too flexible to lend themselves to any simple process of instilling fixed ideas."

The term "simple process" is important in this sentence. Admitted that it is true that it is not a simple process, this does not necessarily imply that Bell thinks ideology does not play any role at all. Elsewhere she (1992:26) rejects a dichotomy between thought and action. As mentioned, Stark's network theory is based on the control theory of deviant behavior, which in turn goes back to Durkheim's theory of social integration. Yet, Durkheim himself cautions against a distinction between thought and action:

Religion is neither exclusively an binding philosophy nor a practical discipline: it is one and the other at the same time. Thought and action are closely united, to the point of being inseparable. It corresponds to a stage of social development where these two functions are not yet dissociated and constituted apart from each other, but are still so entangled in each other that it is impossible to draw a clear line of demarcation between them. Dogmas are not purely speculative states, mere 
phenomena of ideation. They always relate directly to defined practices (Durkheim 1897 \& 1898:20; own translation).

Durkheim's position is ambiguous. Scholars are divided on the primacy of myth or ritual in his writings (Segal 2002:64ff). When this study, with Bell (1992), rejects the dichotomy between thought and action, it assumes that both belief and ritual play a role in the origin of religion, i.c. the Christian religion within the context of the Pauline churches. This study has only focused on the role of ritual, analyzing the role of symbolism in resolving tensions and conflicts in the Corinthian church, which is geared to maintaining and extending the church as an open network. The role of belief is assumed to be important as well, but cannot be discussed within the limits of this study.

\section{Conclusion}

In opposition to the central role attributed to temple symbolism in Paul's view of mission by scholars like Beale and Wright, this study interprets Paul's temple symbolism not as a substance but as an attribute. It can therefore not be used to determine Paul's concept of mission. Symbolism does not provide a fixed meaning; its meaning is dependent on its use (cf Wittgenstein).

In his first letter to the church in Corinth, Paul addresses various problems: divisions, sexual immorality, gifts of the spirit, etc. He uses symbolism, in particular the symbolism of the household, building, temple, body, Passover, Kingdom and cosmic battle, to reconfigure the vision of the order of power within the church.

Through symbolism, the experience of a quarrel within the church at Corinth is transformed from being a struggle for status/honor between members ("I belong to Paul" or "I belong to Apollos"), to a larger issue that involves the identity of the members and God's presence within the community. He reconfigures the vision of the order of power within the church, where the real issue is not whether you belong to Paul, Apollos or Cephas, but whether you belong to Christ or Satan. Paul thus prevents the Corinthian church to evolve into factions and instead seeks to maintain and extend it as an open network with Christ as Lord.

\section{References}

Anderson, R. D. 2008. 1 Korintiërs: orde op zaken in een jonge stadskerk. Kampen: Kok. Beale, G. K. 2004. The Temple And The Church's Mission: A Biblical Theology of The Dwelling Place of God. Downers Grove, Ill: Inter-Varsity Press.

Beker, J.C. 1980. Paul The Apostle. The Triumph of God In Life And Thought. Philadelphia: Fortress press.

Bell, C. 1992. Ritual Theory, Ritual Practice. New York: Oxford University Press. 
Bell, C. 1997. Ritual. Perspectives And Dimensions. New York: Oxford University Press.

Bosch, D. J. 1991.Transforming Mission: Paradigm Shifts In Theology of Mission. Maryknoll, N.Y.: Orbis Books.

Brouwer, L. 2015. Mission and hospitality: a literary ethnography of the Pauline churches. ThD thesis, University of South Africa.

Brümmer, V. 2006. Brümmer on meaning and the Christian faith: collected writings of Vincent Brümmer. Aldershot: Ashgate Publishing.

Bultmann, R. 1924. Das Problem der Ethik bei Paulus. Zeitschrift fur die neutestamentliche Wissenschaft 23, 1:123-140.

Bultmann, R. 1951. Theology of The New Testament. New York: Charles Scribner's.

Butterworth, E. A. S. 1970. The Tree as the Navel of the Earth. Berlin \& New York: Walter de Gruyter \& Company.

Clements, R. E. 1965. God And Temple. Philadephia: Fortress Press.

Clifford, R. J. 1972. The Cosmic Mountain In Canaan And The Old Testament. Cambridge, Mass: Harvard University Press.

Collins, A. Y. 1998. Pergamon in Early Christian Literature, in Helmut Koester, ed., Pergamon, Citadel of the Gods: Archaeological Record, Literary Description, and Religious Development. Harrisburg, PA: Trinity Press International, 163-184.

Collins, A. Y., \& Attridge, H. W. 2007. Mark: A Commentary on the Gospel of Mark. Minneapolis, MN: Fortress Press.

Collins, J. J., \& Collins, A. Y. (1993). Daniel: a commentary on the book of Daniel. (F. M. Cross, Red.). Minneapolis, MN: Fortress Press.

Conzelmann, H. 1975. 1 Corinthians: a commentary on the First Epistle to the Corinthians. Philadelphia: Fortress Press.

Cross, F.M. 1973. Canaanite Myth And Hebrew Epic: Essays In The History of The Religion of Israel. Cambridge, MA: Harvard University Press.

Csordas, Th. J. 1994. The Sacred Self: A Cultural Phenomenology of Charismatic Healing. Berkeley, CA: University of California Press.

Dibelius, M. 1927. An die Kolosser, Epheser, an Philemon erklärt. Tübingen: J.C.B. Mohr.

Doran, R. 2012. 2 Maccabees: a critical commentary. Minneapolis, MN: Fortress Press.

Dumont, L. 1998. Homo Hierarchicus: The Caste System And Its Implications; translated by Mark Sainsbury, Louis Dumont, and Basia Gulati. Complete revised English edition. Oxford: Oxford University Press.

Durkheim, E. 1897-1898. De la définition des phénomènes religieux. Année Sociologique. 2:1-28.

Eliade, M. 1959. The Sacred And The Profane: The Nature of Religion; translated from the French by Willard R. Trask. New York: Harcourt Brace \& World.

Eliade, M. 1960. Lebensbaum. Religion in Geschichte und Gegenwart 3rd ed. Tübingen: J.C.B Mohr.

Engberg-Pedersen, T. 2000. Paul And The Stoics. Edinburgh: T. \& T. Clark, 2000.

Fishbane, M. 1998. Biblical Text And Texture: A Literary Reading of Selected Texts. Oxford: Oneworld. 
Fitzmyer, J.A. 2008. First Corinthians a new translation with introduction and commentary. New Haven; London: Yale University Press.

Goody, J. 1961. Religion and ritual.The definitional problem. British Journal of Sociology 12:2, 142-164.

Grimes, R. 1990. Ritual Criticism: Case Studies In Its Practice, Essays On Its Theory. Columbia, South Carolina: University of South Carolina Press.

Hasel, G. 1972. Old Testament Theology. Basic Issues In The Current Debate. Grand Rapids, MI: W.B. Eerdmans.

Hayward, C.T.R. 1996. The Jewish Temple: A Non-Biblical Sourcebook. London \& New York: Routledge.

Humphrey, C. \& Laidlaw, J. 1994. The Archetypal Actions of Ritual: A Theory of Ritual Illustrated By The Jain Rite of Worship. Oxford: Clarendon Press.

James, E. 0. 1966. The Tree of Life: An Archaeological Study. Studies in the History of Religions. Leiden: Brill.

Lee, M. V. 2006. Paul, the stoics, and the body of christ. Society for New Testament Studies Monograph 137. New York: Cambridge University.

Levenson, J.D. 1984. The Temple and the World. The Journal of Religion 64:3, 275-298.

Levenson, J.D. 1985. Sinai And Zion: An Entry Into The Jewish Bible. New York: Harper Collins.

Levenson, J.D. 1988. Creation and the persistence of evil: the Jewish drama of divine omnipotence. Princeton: Princeton University Press.

Margulis, B. 1971. A Weltbaum in Ugarithic literature? Journal of Biblical Literature 90:481-482.

Margulis, B. 1974. Weltbaum and Weltberg in Ugaritic literature: notes and observations on RS 24:245. Zeitschrift Für Die Alttestamentliche Wissenschaft 86:1, 1-23.

Martin, D. B. 1995. The Corinthian body. New Haven: Yale University Press.

May, H.G. 1962. The King in the Garden of Eden. A Study of Ezekiel 28:12-19. In Anderson,

B.W. \& Harrelson, W. (eds): Israel's Prophetic Heritage; Essays In Honor of James Muilenburg. New York: Harper.

Meeks, W. A. 1983. The First Urban Christians: The Social World of The Apostle Paul. New Haven: Yale University Press.

Moore, G. F. 1970. Judaism In The First Centuries of The Christian Era: The Age of The Tannaim. Cambridge: Harvard University Press.

Neill, S. 1966. Colonialism and Christian missions. New York: McGraw-Hill.

Said, E. 1994. Culture \& Imperialism. London: Vintage.

Segal, R.A. 2002. Robertson Smith's influence on Durkheim's theory of ritual. In Idinopulos, T. A. \& Wilson, B. C. (eds): Reappraising Durkheim for the study and teaching of religion today. Leiden: Brill.

Staal, F. 1979. The meaninglessness of ritual. Numen 26:1, 2-22.

Stark, R. \& Bainbridge, W. S. 1996. Religion, deviance, and social control. New York: Routledge.

Stark, R. 1996. The Rise of Christianity. A Sociologist Reconsiders History. Princeton, New Jersey: Princeton University Press. 
Taylor, Ch. 2007. A Secular Age. Cambridge, MA: The Belknap press of Harvard University press.

Terrien, S. 1978. The elusive presence: toward a new Biblical theology. San Francisco: Harper \& Row.

Waardenburg, J. 1978. Reflections On The Study of Religion. The Hague: Mouton.

Walton, J. H. 2001. Genesis. The NIV Application Commentary. From Biblical Text . . To Contemporary Life. Grand Rapids, MI: Zondervan.

Walton, J. H. 2006. Ancient Near Eastern Thought And The Old Testament: Introducing The Conceptual World of The Hebrew Bible. Grand Rapids, MI: Baker Academic.

Widengren, G. 1951. The King and the Tree of Life in Ancient Near Eastern Religion. Lundequistska, Uppsala: Uppsala Universitets Arsskrift.

Wright, C.J.H. 2006. The Mission of God: Unlocking The Bible's Grand Narrative. Downers Grove: IVP Academic.

Wright, N.T. 2013. Paul And The Faithfulness of God. Vol. 1. London: Society for Promoting Christian Knowledge.

Zimmerli, W., Cross, F. M., \& Baltzer, K. 1979. Ezekiel: a commentary on the Book of the Prophet Ezekiel. Philadelphia: Fortress Press. 